\title{
ON-LINE SERIALS SYSTEM AT LAVAL UNIVERSITY LIBRARY
}

Rosario de VARENNES: Director, Library Analysis and Automation, Laval University Library, Cité Universitaire, Québec, Canada

Description of a system, operational since June 1968, that provides control of all serials holdings in nine campus libraries, permits updating of the complete file every two or three days, and produces various outputs for library users and library staff from data in variable fields on disks (listings, statistics, etc.). The program, presently operating on an IBM 360/50 and utilizing an IBM 2314 disk-storage facility and three IBM 226 CRT terminals, is written in IBM System/360 Operating System Assembler Language and in $P L / I$; it could encompass a file of no more than 10 million records of variable length limited to $127 / 255$ characters and subdivided in 25 or fewer fields.

L'Université Laval, the oldest French university in America, around 1950 began a move from the original location in historic Old Quebec to a new campus in suburban Sainte-Foy; the general plan calls for a total investment of $\$ 235,000,000$. This private institution, subsidized by the Provincial Government at about $75 \%$, had an operating budget in 1968/69 of $\$ 32,000,000$ (research not included); of this sum, $\$ 2,300,000$ was appropriated for the library system. The enrollment of full-time students was 10,145 and the total registration 22,726. The regular teaching staff amounted to 1,016 and the total figure was 1,691 .

The library serving this community constitutes a unified system under one administration, with centralized technical processing, but with nine physical locations-one of which is still in the Old City-and four auxiliary services: Documentation Center, Rare Books and Archives, Map Li- 
brary and Film Library. The most recent addition to it is the Main Library Building, dedicated in June 1969 , a $\$ 10,000,000$ seven-story complex of 424,000 square feet(1). The Library staff consists of 269 employees, of which 78 are professional librarians or specialists. The Serials Department totals fifteen employees, of which three are professional librarians. The collections as of August 1969 represent 815,966 physical units, or 433,407 cataloging units of books, periodicals, government publications, pamphlets and microtexts; and 88,734 physical units of special collections (maps, photos, films, fixed films, music records, manuscripts, archives). The serials alone account for 189,440 bound volumes and 16,335 titles, of which 12,396 are received currently and 7,934 are subscriptions. The figures for serials titles will probably reach the 20,000 mark with the completion in 1970 of an inventory started in 1964.

Library automation venture at the Library goes back to the autumn of 1963, when an off-line serials system and a subject headings list program were begun. Along the road, there was developed in the Documentation Center a special technique of information storage and retrieval utilizing the Recordak Miracode (Microfilm Retrieval Access Code) System and a program called ASYVOL 2 (Analyse Synthétique par Vocabulaire Libre/Synthetical Analysis by Free Vocabulary) by means of which various indexes and research projects are currently processed. Recently the first on-line real-time program with the new serials system went into successful operation. Some literature, mostly in French, has been issued concerning these realizations and projects, but has been little publicized (2-11). It is also worth noting that the Library, except for some peripheral equipment, mostly input devices, does not own any machinery and is utilizing instead the programming staff and the computer facilities of the polyvalent Laval University's Computing Center. In the Library itself the author of this article is mainly responsible for preliminary analysis of projects, for coordination of activities between the Library and the Computing Center, for the supervision of work done in library automation units integrated into library services, and for the administration of the budget appropriated for library automation. This last item, research projects not included, is $\$ 170,000$ for the year under discussion.

\section{SYSTEM DESIGN}

\section{Contents of the File}

In its present organization, the serials file is accessible only by an accession number limited to seven digits and ordered corresponding to the alphabetized entries of records. There is a distinct entry for every title and every reference and for each duplication of any one title or reference. All records fall within two main divisions: humanities, represented by $H$, and sciences, represented by $S$, and are further identified by subdivisions of these main classes to a limit of three letters (for 
Journal of Library Automation Vol. 3/2 June, 1970

MATRICULE NO:


N.B. SIGLE
lère col
1 courent
2 col 1 publication officielle
3e col 1 annuel ou continuation
4e col. 1 voir
non courant
6e col. 1 périodiques d'hepitaux
o non officielle
0 les autres
- titre du périodique
o collection complète

Fig. 1. Input Sheet. 

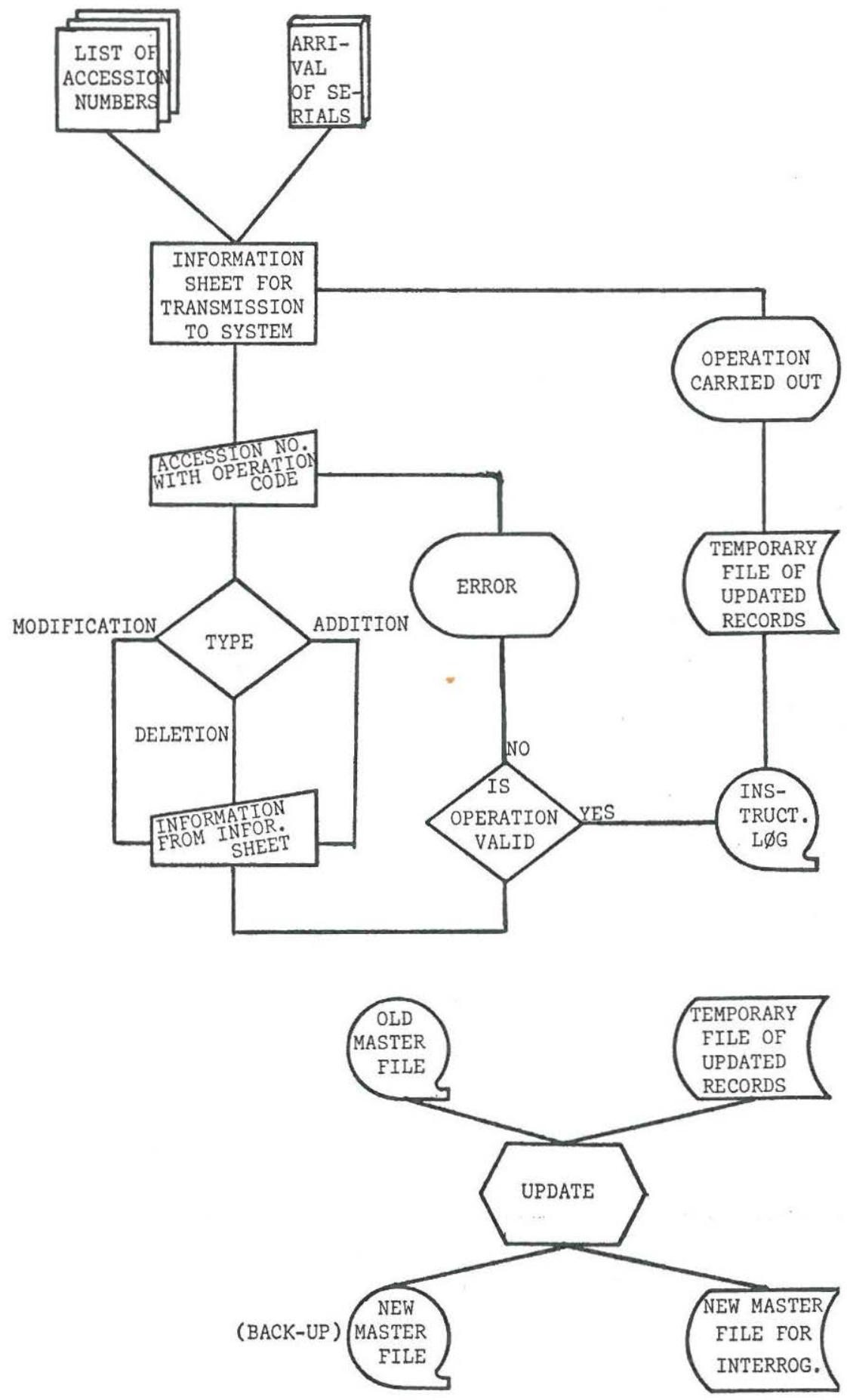

Fig. 2. Serials File Updating. 
example: $H H$, Main Library; $H M U$, Music Library; SA, Agricultural Library; SCC, Science Library, Department of Chemistry). There is a possibility of 25 fixed/variable fields for any record, but only 18 are currently used (Figure 1). As of September 2, 1969, the statistical figures for the complete file were as follows: 22,530 entries, of which 16,335 were titles; 6,192 references; three entries were unspecified by error.

\section{Hardware}

The system is operational with an IBM 360/50, an IBM 2314 diskstorage facility and IBM 2316 disk packs, three IBM 2260 CRT display units, an IBM 2848 display control unit, an IBM 2401 tape transport and control unit and an IBM 1403 high-speed printer. The program system occupies a 56,320-byte region of core memory.

\section{Software}

The system developed at Laval provides essentially for two things: the record display on CRT terminals for questioning or modifying the records; and the updating of the serials file (Figure 2). It is not affected by the bibliographic contents of records; the control of this part is the responsibility of the Serials Department. The system could encompass any file of no more than 10 million records of variable length limited to $127 / 255$ characters and subdivided into 25 or fewer fields.

The program is written in IBM System/360 Operating System Assembler Language, except for the output and printing routines written in $\mathrm{PL} / \mathrm{I}$, and it is conceived for an IBM 360/30 model or one of a higher number, matched at a minimum with one magnetic tape, one disk, one 2848 Control Unit and one 2260 CRT terminal; it operates under the control of operating system OS/360, version 14 or subsequent $(12,13)$.

The system is roughly subdivided into three subsystems, the first being the control routine for the system and CRT terminals, developed by the



Fig. 3. Communication between Modules. 
Computing Center of Laval University and called RACINE (ROOT).

The second is a subsystem that consists of display and updating routines, a group of 18 modules falling under two control sections (CSECT): LINKAGES and MARCHAND (family name of an analyst-programmer from B.I.R.O.). Each is again constituted of various subprograms, and MARCHAND includes also all literals of the program. All these modules communicate various ways as illustrated in Figure 3. Modules not within the large box constitute the CSECT MARCHAND; other CSECT are within the large box.

The third subsystem is a modification routine of records on disk called MODOSSIF (Modification des Dossiers du Fichier/Modification of Records on File).

The IBM/Linkage Editor links these routines, and they communicate 1) by way of specific registers; and 2) by way of working space areas, some common to all terminal stations and some restricted to one in particular.

The main purpose of the system being to give the user up-to-date information, it is implied that information concerning modified records should be available as soon as the transaction is performed. The IBM/ Indexed Sequential System seems at first sight to ideally answer this need. Nevertheless, the Library was forced to elaborate a more complex system for the sake of security.

Data Sets (Figure 4)



Fig. 4. Data Sets. 
There exist the master file in direct access on disk, with a backup file on tape. When a record is asked for, the accession number of the record is transmitted to the program and searched for in the file; if found it is duplicated completely in the working space area on disk corresponding to a particular terminal, and is displayed on the CRT nine lines at a time. In case of a modification being asked for, it is on this copy in that particular area that the program MODOSSIF applies. In switching to another demand, the program checks to see if any modification occurred. If not, the copy is destroyed; otherwise the amended record is transferred to the temporary common working space area on disk called BPAM (Buffer Périodiques Amendés/Buffer Amended Serials), where all modifications accumulate from one updating of the master file to the other. If queried anew before updating, the same amended record will be retrieved from BPAM file and duplicated as before.

Moreover, any instruction concerning modifications is chronologically recorded on tape as given and constitutes the LOG (Figure 2). If any down time occurs, it is then possible to simulate all the transactions performed since the last updating. Updating, normally a daily process, is basically the merger of the master file with the BPAM file, resulting in the creation of a new master file on disk and a new backup on tape.

\section{Record in the File}

As mentioned before, any record in the file is identified by an accession number of seven digits. Number 0000000 identifies the system's messages and is always displayed first, and number 9999999, indicating that a working space area is not occupied, is not to be used. Otherwise all numbers are symmetrical and interchangeable.

Any record may cover up to 25 fields or blocks of logical information. These fields are identified by letters $A$ to $Y$ and put into alphabetical order. They vary in length from three to many thousand characters.

Each field is divided into three elements: identifying letter; information to display; and end of field or record control tag. This tag is FD (Fin du Dossier/End of Field) for all fields except the last one, which is tagged FE (Fin de l'Entrée/End of Record). The information to be displayed is submitted to various restrictions, exemplified in detail in the instructions manual (13). The manual, in fact, puts in action the main program MODOSSIF.

Physically any record on file is subdivided into many subrecords of fixed length ( $L E Q U n n n$ ) optimized at 239 bytes to a maximum of 127 per record. Each subrecord is addressed in three sections as follows: 235 bytes of information, three bytes representing the accession number in binary code and one byte giving the sequence number of the subrecord under this particular accession number. This way, the last four bytes give the key to the subrecord in the master file and the last byte the key of access in the working-space area, making it possible to execute 
MODOSSIF and various print-out routines. To facilitate the retrieval of any particular field in a record, the 26 first bytes of the first subrecord are set aside for an index to the fields. The 25 first bytes represent fields $A$ to $Y$; in each position, a binary zero points to an inexistent field and a positive value indicates the sequence of the subrecord where the field starts. The 26th byte gives the total number of subrecords in the record. The 27th byte gives the name of the first existing field, etc.

Figure 5 is an example of a complete record. Underlined sections indicate hexadecimal notation. Each row in the figure is a subrecord here given an unreal value of 40 . The remainder is in alphanumeric characters, except that space is compressed and indicated by a dollar sign. The information on Figure 5 appears as follows on the CRT screen:

$\begin{array}{lll}\text { A } & \text { TOKYO BUNRIKA DAIGURU, SCIENCE REPORTS } \\ \text { B } & 000010 & \text { SC } \\ \text { D } & \text { ANNUAL REPORTS OF SCIENCES } & \\ \text { Q } & \text { NO 50-67, 83, 97 } & \\ \text { T } & \text { CHIMIE } & \\ & \text { CHIMIE INDUSTRIELLE } & \text { C } \\ \text { U } & \text { A ET B } & \text { C } \\ \text { V } & \text { A - B } & \text { VIDE } \\ \text { W } & & \\ \text { X } & \text { REVUE ANNUELLE DE CHIMIE } & \\ \text { Y } & \text { CE DOSSIER EST DRESSE A TITRE D'EXEMPLE } \\ & \text { SEULEMENT. }\end{array}$

\section{Varia}

The program provides also the parameters for each of the lines displayed on the screen, that is, nine screen-parameters called PARMEC (Paramètres-Ecran).

A B C D E F G H I J K L IN N O P Q R S T U V W X Y $\frac{0102000300000000000000000000000003000004050505050608}{12}$ A T O K Y O B U N $\underline{21 E 88 E 01}$ R I K A D A I G R U, S C I E N C R E P O R T S FDB $0000010 \underline{21 E 88 E 02}$ \$S C $50-67,83,97$ FDT C H I M I E - C H I II I E I N D U S T R I E 21E88E04

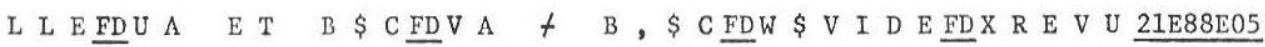
E A N N E L LE DE C H I M I E. FDY C E D O S S I E R E S 21E88E06 T DRESSE A TITRE D'EX E P L E S E U LE M E T T 21E88E07 - FE00000000000000000000000000000000000000000000000000000000000000000000 21E88E08 Fig. 5. Example of Complete Record. 
The analyst-programmers at the Computing Center completed the program by various printing subprograms from the data on variable fields on disks, by a statistics subprogram and by a control routine of the indexes to the file.

Recently another addition occurred to the system when Les Presses de l'Université Laval, the Library's subscription agent for serials, decided to utilize the file to initiate a computerized ordering process. The programming for this project was tested during October and the program was successfully run during the first week of December 1969.

\section{IMPLEMENTATION}

As soon as it was confirmed that the Computing Center would receive by Summer 1967 a third-generation computer (IBM 360/40) it was deemed advisable to contemplate an on-line system to replace the already saturated off-line serials system on the IBM 1410 inaugurated in 1964 (8). An optimistic target date having been set for January 1968, the author transmitted in April 1967 to the Computing Center for study a working hypothesis concerning the automatic conversion of holdings data and the automatic claiming of missing issues (14). In answer to it, in August 1967, Mr. Jean Lachance, analyst-programmer, proposed a first draft of an automatic control system for serials (15). In fact the draft envisaged only a semi-automatic conversion of data and the on-line system for current entries only, the non-current being managed off line. Then, on account of various restrictions befalling the Computing Center, it was decided to call upon an external firm, B.I.R.O., Inc., located in Quebec City. The contract, signed at the end of November 1967, provided basically for: 1) the conversion of the master file on magnetic tapes, containing records in fixed fields, to a random access file on disks, with records in variable fields; 2 ) the programming of record display on CRT terminals; 3 ) the updating of the file via coded input procedures; 4) the provision of transitory working space areas for current transactions; 5) the possibility of questioning and amending both the master file and the transitory file; 6) the writing of the appropriate technical documentation and the intitial training of the operators of the terminals. The contract was to be in conformity with the standards of operating system OS for an IBM 360 computer and subject to the acceptance of the Computing Center of Laval University. At the same time a working schedule was established as follows: 1) beginning of work as soon as the contract was signed; 2) operational program sixty days after delivery to the contractor of terminals in good working condition according to manufacturer's specifications; and 3 ) termination of contract thirty days after acceptance of the finished product.

The terminals were ready by January 25,1968 . The program was declared operational by April 11, 1968, and the technical report describing it deposited the week after. Meanwhile a last updating of the master 
file with the off-line system was performed at the beginning of April. On April 29, 1968, the conversion of the file to IBM 2311 disks connected to an IBM 360/40 was realized. Everything was then ready for the final test. Unhappily, Mr. Lachance left Laval at the end of April at the most crucial moment, and it was not before June 12, 1968, that the first updating succeeded and the program became operational. From then on, apart from various technical problems, there were other diffculties: a moving of the main library during August, a moving of the Computing Center that precluded any activity from September 26 to October 25, and a switch to an IBM 360/50 and to an IBM 2314 diskstorage facility during October-not to mention a turnover of staff in the Serials Department. These prevailing conditions explain why the program was not officially accepted by the Library before December 16, 1968.

\section{OPERATION}

The first of a series of turning points in the refinement of the program occurred in November 1968 with a normalized run of updatings. In January 1969 the two first printing programs ran successfully; these were a daily checking list with calendar, and a statistics subprogram (Figure 6). In February 1969 the program produced almost error-free updatings (0.8\% and $0.63 \%$ ), and in June 1969 the system was finally debugged, eliminating a particular recurring anomaly accounting for most of the errors in the system (a display of preceding instruction bearing accession number and code in some field of subsequent record).

Some other technical difficulties were encountered along the road and

tableau des statistiquesifichier des periodiquesi

2 SEPTEMBRE 1969.

SECTEUR $S$



**ERREURS $=\quad 8$

** nombre de dossiers qui sont des titres courants et qui n'ont pas de champ new = 4

Fig. 6. Some Outputs. 
diversely overcome; for example, incomplete reading of LOG, down time, overlapping of information, duplication of fields, unaccepted records, display of information into frame or display of frame of inexistent field, unsettled screen, etc.

In the fifteen months after June 1968, the input capability per person improved from an average of 30-35 transactions a day during the first three months to an average of 100-200 transactions a day, depending on the length of records; the down time was reduced from 50\% to $10 \%-15 \%$ and even less than 5\% for some weeks; the error percentage attributable to program-as distinct from errors of transcription-has declined from $10 \%-5 \%$ to $1 \%$ or less.

To familiarize library staff with the new system and build confidence in it, a round of systematic demonstrations of the system at terminal points was organized as part of an in-training program. Two printed guides $(16,17)$ were previously distributed; then from February 5 to March 14, 1969, all employees, in groups of six, were directed in questioning the file individually by sitting down at the consoles and pressing the right tabs. Later the experience was completed by a guided tour in larger groups to the machine room of the Computing Center. Members of the staff were enthusiastic, especially the professional people, and the experiment on both sides quite a success.

An initial feature of the new system, but one which has not yet materialized, is the automatic claiming of missing issues. A first step in this direction will be initiated with the recent subprogram prepared for automatic ordering of serials at Les Presses de l'Université Laval. CODEN may be introduced into the system and a question-answer subprogram devised that would give a more selective approach to the file-in fact, an application of IBM/DPS (Document Processing System) to a sample of some 200 records has already been positively tested. As for the hardware, there is a good possibility of installing terminals for users in main libraries in 1970/71. It also seems quite realistic that the system will be switched again to an IBM $360 / 67$ in the near future.

\section{DISCUSSION}

It may rightly be said that at the start of the 70 's, the library field has come half way to the materialization of the "on-line, total library system" concept as defined by Robert M. Hayes in 1965, and also that the manufacturers are on the verge of offering libraries the "computer service centers" fitted to their particular needs as forecast by the same author (18). On the one hand, indeed, numerous examples of operational online applications to various library functions have been described in the Journal of Library Automation, as well as in other specialized publications (the LARC Reports, Program, Special Libraries, etc.). On the other hand, pertinent literature on library automation issued by people or firms from the data processing and computer fields-for example, Warheit (19), 
IBM, SDC (20) - and diversified services under contract executed by computer firms for library organizations, are sufficient proof that manufacturers are now heeding this new market of computer applications. It is only to be hoped that these firms will also realize the linguistic dimensions of their new market and will accelerate the extension of their publications program to languages such as French, Spanish, etc., with special emphasis on French for the French-speaking population of Canada.

Concerning Laval University's on-line serials system, it is still too soon to be in a position to evaluate its impact on the Library's environment. The system is still in the building and not yet really exploited, especially from the user's point of view. There are other shortcomings of the present program. It's only access by accession number is far too limiting for on-line dialogue. It is questionable whether it was advisable to have divided the holding statement in two parts (summary notation of what is in field $Q$, to conform to regular practice, and detailed notation of missing issues in field $R$, for acquisition purposes) on account of the heavy routine it imposes on library staff; questionable also is the double entry for titles in A (regular librarians' practice) and $M$ (direct title) on account of complexities it bears with it for references. A lack of consultation with B.I.R.O., Inc., in the initial phase of the contract led to the establishment of a field sequence not ideally compatible with the requirements of the Serials Department's daily operations, though adjusted to optimum storage capacity. A more complete mastery of downtime periods and a more effective and more reliable routine of restart should have been developed by now by the staff of the Computing Center. Finally, there has not been a total shift from off-line procedures to procedures more compatible with the new system, mostly because of psychological reluctance on the part of library staff.

On the other hand, a far more reliable system keeps serials under better control. The serials file is updated twice or thrice a week-and is indeed "updatable" anytime-without any inconvenience to the Serials Department, whereas in the off-line system the annual or semi-annual updatings were compelling stoppage of regular operations for weeks, or even requiring overtime. There need be no more distinction between current and non-current records, nor with oversized records, since any record of any length is readily acceptable by the system. The opportunity exists of producing more adequate listings of all kinds, and reliable statistics more quickly and at a better price. The input procedure is so simplified that that fact alone would almost justify the system. Finally, "humiliter dico," this program has brought more fame to the library (or is it only curiosity?) than any other achievement, inquiries about it coming from Canada, the U.S.A., England, France, Africa, and even USSR. A year or so from now, it should be possible to evaluate the impact of the system on Laval Library users, by which time additional terminals will have been put at their disposal. 


\section{PROGRAMS}

Microfiches and photocopies of the following may be obtained from National Auxiliary Publications Service of ASIS: "On-Line Serials System at Laval University Library: Basic Programs (NAPS 00966) and "On-Line Serials System at Laval University Library: Printing Programs (NAPS 00967).

\section{ACKNOWLEDGMENTS}

The sustained collaboration, expert advice and friendly understanding of people from the Computing Center of Laval University were important to the Library program from the beginning. The Director, Mr. Louis P. A. Robichaud, scientist of international repute, the Assistant Director, Mr. Pierre Ardouin, and the analysts assigned to the serials program-Mr. Conrad Bourdon and Mr. Richard Desrosiers-skillfully maintain the system and work continuously towards its potential development. Special thanks must also deservedly go to the firm B.I.R.O., Inc., for implementation of the basic programs. Encouragement in this venture by the Librarian-in-Chief, Father Joseph Marie Blanchet, was constant.

\section{REFERENCES}

1. Varennes, Rosario de: "The Siamese Twins Or the New Building of Laval University Library", (Quebec, June 17, 1969) 8 pp.

2. Journée d'Etude sur la Mécanisation de Certains Services de la Bibliothèque de l'Université Laval; Communiqués (Sainte-Foy, Québec: 5 juin 1964), $93 \mathrm{p}$.

3. Communications Présentées à une Réunion de Bibliothécaires d'Universités Canadiennes sur l'Automatisation des Services de Bibliothèque Tenue à l'Université Laval (Québec: 21 et 22 mars 1966), 69 p.

4. Varennes, Rosario de: Summary Report, Committee for Automation of Library Services, Laval Univ. Library, (Quebec, Mar. 18, 1966) 5 pp.

5. Stuart-Stubbs, Basil: Conference on Computers in Canadian Libraries, Université Laval, Québec, March 21-22, 1966; A Report Prepared for the Canadian Association of College and University Libraries (Vancouver: University of British Columbia Library June 1966), $13 \mathrm{p}$.

6. Programme d'Automatisation des Services de la Bibliothèque de lUUniversité Laval (Montréal: ACBLF, Août 1967), 74 p.

7. Forget, Guy: "Rapport sur ASYVOL", In Dolan, F. T.: Information Retrieval in Canada; A Preliminary Survey. (Calgary, Alberta: Imperial Oil Ltd., Producting Dept., Western Region August 1967), IPRC-4 MIR-67, pp. 163-173.

8. Varennes, Rosario de: "Computerized Serials Record at Laval University: A Progress Report”, Canadian Library, 24 (September 1967), 122-123.

9. Leclerc, Rita: "Le Centre de Documentation de la Bibliothèque de l'Université Laval (Québec)", Revue de l'A.UPELF, 5 (Automne 1967), 27-32. 
10. Varennes, Rosario de: Bird's-Eye View of the Library's Computer Programs and Projects as of February 21, 1969. Prepared for the Members of the AUCC (Association of Universities and Colleges of Canada) Library Automation Committee (Québec: Bibliothèque de l'Université Laval, Analyse et Automatisation des Services: February 25, 1969), 9 p.

11. Forget, Guy. "The University Library and Information Center: A New Dimension". In Clinic on Library Applications of Data Processing, University of Illinois, 6th, 1968. Proceedings (Urbana, Ill.: University of Illinois Graduate School of Library Service), pp. 1-10.

12. B.I.R.O. Inc., Québec: Système d'Affichage et de Mise à Jour du Fichier des Périodiques; Documentation Technique (Québec, B.I.R.O. Inc., Avril 1968), 33 p.

13. B.I.R.O. Inc., Québec: Système d'Affichage du Fichier des Périodiques, Bibliothèque de l'Université Laval. Manuel d'Opération (Québec: Centre de Traitement de l'Information, Université Laval. Juin 1968), $58 \mathrm{p}$.

14. Varennes, Rosario de: Programme des Périodiques 1968. Hypothèse de Travail: Conversion Mécanisée des Données de l'Etat de Collection et Rappels Automatiques. Schéma Préliminaire à lintention du Centre de Traitment de l'Information (Québec: Bibliothèque de l'Université Laval, Services des Périodiques. 26 Avril 1967), 6 p.

15. Lachance, Jean: Etudes Préliminaires d'un Système de Contrôle Automatique des Périodiques, Université Laval" (Québec: Centre de Traitement de l'Information, Université Laval: 14 Août 1967), 8 p.

16. Varennes, Rosario de: Guide Succinct pour l'Interrogation du Système de Périodiques en Temps Réel avec l'Ordinateur (IBM 360-50/2314/ 2260). A lintention du Personnel de la Bibliothèque" (Québec: Bibliothèque de l'Université Laval, Analyse et Automatisation des Services: 15 Janvier 1969), $7 \mathrm{p}$.

17. Bourdon, Conrad; Varennes, Rosario de: Description Technique Somnaire du Système de Périodiques en Temps Réel avec l'Ordinateur (IBM 360-50/2314/2260). Complément au "Guide succinct . . . " déjà paru. A l'Intention du Personnel de la Bibliothèque" (Québec: Bibliothèque de l'Université Laval, Analyse et Automatisation des Services: 24 Avril 1969), 8 p.

18. Hayes, Robert M.: "The Concept of an On-Line, Total Library System", Library Technology Reports, Section: Data Processing (May $1965), 13 \mathrm{p}$.

19. Warheit, I. A.: "File Organization of Library Records", Journal of Library Automation, 2 (March 1969), 20-30.

20. Black, Donald V.: Library Information System Time-Sharing on a Large, General-Purpose Computer (Santa Monica, Calif.: System Development Corporation, September 20, 1968) SP-3135, 21 p. 